\title{
Bioaccumulation of organochlorine pesticide residues in fish and invertebrates of Lagos Lagoon, Nigeria
}

\author{
Alani, Rose'; Drouillard, Ken²; Olayinka, Kehinde" ${ }^{\star 1}$; and Alo, Babajide ${ }^{1}$. \\ 1. Chemistry Department, University of Lagos, Nigeria, Africa, and \\ ${ }^{2}$ Great Lakes Institute for Environmental Research (GLIER), University of Windsor, ON, \\ Canada \\ profjidealo@yahoo.com, 2348022903841; *keolayi20002000@yahoo.com, 2348023204841; \\ kgd@uwindsor.ca, (519) 253-3000 ext: 2732; and ralani@unilag.edu.ng, 2348025213236
}

\begin{abstract}
The rate at which organochlorine pesticides (OCs) are being used in Nigeria is becoming a matter of concern considering the heavy negative health effects associated with these chemicals. OCs are very persistent, bioaccumulative and toxic, and they can easily find their way into an adjacent water course such as the Lagos Lagoon via soil run-off and leaching. The levels of OCs were therefore assessed in water, sediment, invertebrates (crayfish shrimps and crabs) and twelve species of fish, including commercially important fish sold to local markets. Samples were collected and analyzed using Gas chromatography/ Mass selective Detector (GC/MSD). The most bioaccumulated OCs in the fish were beta-HCH (22.72-0.90ng/g d. w.) and p,p'DDE (16.04$0.44 \mathrm{ng} / \mathrm{g} \mathrm{d}$. w.). The most bioaccumulative OCs in the invertebrates were still beta-HCH (24.50$16.10 \mathrm{ng} / \mathrm{g} \mathrm{d}$. w.) and p,p'DDE (22.20-1.85ng/g d. w.). The sum OCs of $55.22 \mathrm{ng} / \mathrm{g} \mathrm{d}$. w. in crab eggs, 63.90ng/g d. w. in agaza (Caranx hippos), and $69.40 \mathrm{ng} / \mathrm{g} \mathrm{d}$. w. in young blue crabs (Callinectus amnicola) revealed these biota as the most contaminated. Spatial patterns of contaminant accumulation were contrasted between environmental media and biological samples and a risk model for human exposures of organochlorine pesticides due to consumption of contaminated fish and invertebrates is presented.
\end{abstract}

Keywords: Ecological Risk Assessment, OCs, Fishes, Invertebrates, Lagos Lagoon.

\section{INTRODUCTION:}

In Nigeria, organochlorine pesticides like DDT, lindane, etc, are still very much in use for pest control and as insecticides. Commercial DDT mixtures such as zerdane, anofex, chlorophenoethane are imported into the country and marketed for this purpose. People that live at the shores of Lagos Lagoon are quite exposed to insects that are vectors of diseases, including malarial mosquitoes and the ectoparasites that transmit typhus. This has resulted in high use of these OCs for the control of these vectors. There are high tendencies of these OCs being circulated by air masses as well as washed into the lagoon during rainy season and via the drainage systems. OCs can be strongly bioaccumulated by aquatic organisms on getting into an aquatic environment. The higher the octanol- water partition coefficient (Kow) of these chemicals, the lower the water solubility, the more persistent, and the more the tendency to bioaccumulate, (Arnot and Gobas, 2003). Fish can "excrete" many lipophilic xenobiotics by diffusion across the gills into ambient water. Loss by diffusion tends to be effective for compounds of Kow close to 1 , but less so for compounds of very high Kow $\left(1 \times 10^{5}\right.$ and above). OCs, have $\mathrm{MW}<450$ and so can diffuse into membranes, but show little tendency to move out again, (Timbrell, 1999). Uptake could occur in the aquatic organisms via diffusion, water, and food or sediment ingestion, resulting in bioconcentration, bioaccumulation, biotransformation, metabolism, and/or biomagnification. The most important route of uptake depends on the physicochemical properties of the chemical as well as the habitat, the diet and the physiological properties of the organism (Leeuwen and Vermeire, 2007).

The Lagos lagoon, the study area, is one of Africa's largest urbanized estuarine ecosystems. The lagoon borders the forest belt and empties directly into the Atlantic Ocean at the harbor. Its estimated area is $150.56 \mathrm{~km}^{2}$ (Webb, 1958). Lagos Lagoon finds its use in recreational purposes, transport, direct dumpsite for industrial, agricultural \& municipal wastes, and 
even dumpsite for sewages at some of the locations. The lagoon is impacted by industrial, agricultural, municipal, shipping and other oil related activities. The same Lagos Lagoon is an important habitat for a wide array of fish and marine organisms and is the major source of seafoods to the people of Lagos. With the rate at which organochlorine pesticides are being used in Lagos, high concentrations of these chemicals are expected in the Lagos Lagoon.

Out of the twelve PBTs (persistent, bioaccumulative and toxic chemicals) identified by UNEP as the "dirty dozen", eight are OCs, (Walker, 2009), (Colin et al., 2004), (Wells, 1993). It was therefore necessary to assess these PBTs in the biota as their bioaccumulation in aquatic biota could serve as a good indication of pollution problem in the marine environment. Fish and invertebrates collected for this study reflected those consumed by the local population. On exposure there is a tendency for these PBTs to bioaccumulate through food web and pose a risk of causing adverse health effects (Eljarrat and Barcelo, 2003) on humans. OCs have been linked to serious health effects such as reproductive failures, neonatal damage, birth defect, endocrine disruption, immune system dysfunction, and cancer, (Saxena et al., 1981), which makes the exposure to these substances quite unsafe. Assessment of OCs in the biota is useful in establishing a good link to risks related to human exposure to these compounds in the lagoon. Thus the objective of this study is to provide baseline information on the level of OCs, their bioaccumulation and the risk they pose to humans that depend on fish and invertebrates from the Lagos lagoon for food.

MATERIALS AND METHODS:

Sampling: All samples were collected from six locations which were chosen based on their distinguishable locations and were positioned by a global positioning system (GPS). Water samples (IL volume) were collected from the surface using a precleaned (washed with warm water and liquid soap using a brush, after which it was properly rinsed with tap water and dried for 24 hours. The bottles were then rinsed with acetone and allowed to dry for about 30 seconds, and then rinsed with n-hexane) Winchester amber glass bottle by hand. Sediment samples were collected using a Van Veen Grab sampler operated from a boat at the depths between 0.5 and $10 \mathrm{~m}$. Fish and invertebrate samples were collected by trapping overnight; to be representative of frequently consumed food items. The samples were identified, frozen and taken to GLIER, University of Windsor, where they were individually weighed, measured, and stored in the cold room below $4^{\circ} \mathrm{C}$ prior to preparation and analysis. Table 1 summarizes the biological samples collected according to species, length and weight ranges sampled.

Table 1: Biota samples

\begin{tabular}{|c|c|c|c|c|c|}
\hline $\mathrm{S} / \mathrm{N}$ & FISH NAME & Collection location & $\begin{array}{l}\text { Number of } \\
\text { sample }\end{array}$ & $\begin{array}{l}\text { Length (mean } \\
\text { and range) }(\mathrm{cm})\end{array}$ & $\begin{array}{l}\text { Body weight } \\
\text { ranges }(\mathrm{g})\end{array}$ \\
\hline 1 & Caranx hippos (Agaza) & Okobaba & 3 & $10.4-12.7$ & $24.43-67.69$ \\
\hline 2 & Mugil cephalus (mullet) & Okobaba & 2 & 20.2 & $58.13-150.2$ \\
\hline 3 & Sphyraena barracuda (barracuda) & Aja & 2 & $17.9-19.2$ & $106.10-126.31$ \\
\hline 4 & $\begin{array}{l}\text { Sarotherodon melanotheron } \\
\text { (Tilapia) }\end{array}$ & Unilag lagoon front & 2 & $13.0-16.4$ & $53.19-70.54$ \\
\hline 5 & Tilapia guineensis (Tilapia) & Unilag lagoon front & 2 & $12.6-14.1$ & $50.52-54.24$ \\
\hline 6 & Ethmalosa fimbriata (Bonga) & $\begin{array}{l}\text { East of Palava } \\
\text { Island }\end{array}$ & 3 & $146-17.5$ & $47.22-55.81$ \\
\hline 7 & Tarpon atlanticus (megalops) & Unilag lagoon front & 1 & 82.4 & 1880 \\
\hline 8 & $\begin{array}{l}\text { Scomberomorus tritor (mackerel) } \\
\text { (Ayo) }\end{array}$ & Aja & 1 & 21.3 & 86.34 \\
\hline 9 & $\begin{array}{l}\text { Lutjanus agennes (African red } \\
\text { snapper) }\end{array}$ & Okobaba & 2 & $21.2-24.5$ & $108.60-168.12$ \\
\hline
\end{tabular}


Am. J. Sci. Ind. Res., 2013, 4(1): 22-30

\begin{tabular}{|l|l|l|l|l|l|}
10 & Pomadasys jubelini (Grunter) & Okobaba & 1 & 17.5 & 84.6 \\
\hline 11 & $\begin{array}{l}\text { Chrysichthys nigrodigitatus } \\
\text { (Catfish) (Inaha) }\end{array}$ & Five cowrie creek & 1 & 30.3 & 145.63 \\
\hline 12 & $\begin{array}{l}\text { Lutjanus dentatus (African brown } \\
\text { snapper) }\end{array}$ & Okobaba & 1 & 27.9 & 202.31 \\
\hline 13 & Penaeus (Crayfish) & Unilag lagoon front & 20 & $4.2-5.3$ & $1.92-4.36$ \\
\hline 14 & $\begin{array}{l}\text { Macrobranchium vollehoevenii } \\
\text { (Shrimps) }\end{array}$ & Mouth of Ogun River & 7 & $9.1-10.3$ & $15.83-19.19$ \\
\hline 15 & $\begin{array}{l}\text { Callinectes amnicola (young blue } \\
\text { crabs) }\end{array}$ & Unilag lagoon front & 7 & $5.2-6.0$ & $27.87-34.16$ \\
\hline 16 & $\begin{array}{l}\text { Callinectes amnicola (matured } \\
\text { blue crabs with eggs) }\end{array}$ & Mouth of Ogun River & 3 & $10.9-12.6$ & $95.32-116.24$ \\
\hline
\end{tabular}

Sample extraction and analysis: Sample extractions were carried out according to (Lazar et al. 1992). Moisture and organic carbon contents of the sediments were also determined. Sample extracts obtained after florisil cleanup were combined and rotoevaporated to $1 \mathrm{ml}$ and analyzed for organochlorine pesticides (OCs) by gas chromatography. Analysis was run on a HewlettPackard (Avondale, PA) Model 5890/5970 Gas Chromatograph with a mass selective detector (quadrupole mass analyzer, $70 \mathrm{eV}$ ) equipped with a Hewlett-Packard 7673A autosampler and a $30 \mathrm{~m} \times$ $0.25 \mathrm{~mm}$. I.D. $X 0.10 \mu \mathrm{m}$ DB-5 film thickness column. $1 \mu \mathrm{l}$ sample was injected using a splitless injection mode at $250^{\circ} \mathrm{C}$ injection temperature and GC-MSD interface temperature of $280^{\circ} \mathrm{C}$. A mixture of three ${ }_{13}$ C-labelled PCBs (13C - PCB 52, 13C - PCB 153 and $13 \mathrm{C}-\mathrm{PCB} 37$ ) was used as surrogate standard. The OCs were identified and quantified by comparison of retention times and spectra of internal standards. The methods reported above included the processing of blanks, duplicates, Standard Reference Materials (SRM) and standard mixtures between each group of samples. The detection limit ranged between 0.02 to $0.06 \mathrm{ng} / \mathrm{g}$. Contaminants that were not detected were replaced with the detection limit value.

\section{RESULTS AND DISCUSSIONS:}

PBT distribution across the sample types at different locations on Lagos Lagoon: Sum OCs in the lagoon water samples were low and ranged from 0.01 to $0.28 \mathrm{ng} / \mathrm{g}$ (table 2). Considering individual OC, p.p'DDT had the highest concentration of $0.16 \mathrm{ng} / \mathrm{mL}$ in the water at Okobaba. This value was above the EQS concentration of $0.01 \mathrm{ug} / \mathrm{L}$. Sum OCs in sediment ranged from 8.65 to $23.17 \mathrm{ng} / \mathrm{g}$ dry weight (table 2). Chlordane and p,p'DDE concentrations of 13 and $2 \mathrm{ug} / \mathrm{Kg}$ respectively, were reported in sediments of Lake Worth, Fort Worth, Texas. In this report Chlordane was not detected but p,p'DDE sediment concentration (ranging from 1.57 to $1.85 \mathrm{ng} / \mathrm{g} \mathrm{d}$. w.) compared well with $2 \mathrm{ug} / \mathrm{Kg}$ obtained in Lake Worth sediments. In the biota, p, p'DDE ranged from 0.44 to $16.04 \mathrm{ng} / \mathrm{g}$ dry weight for fish and 2.06 to $22.21 \mathrm{ng} / \mathrm{g}$ dry weight for invertebrates and therefore were below the ADRIS (Association of Directors and River Inspectors in Scotland) "no harmful effects" concentrations of $100 \mathrm{ug} / \mathrm{Kg}$ for biota (MPMMG 1998). Also $17.08 \mathrm{ng} / \mathrm{g}$ dry weight $\mathrm{g}-\mathrm{HCH}$ was found only in young crabs and it was below the $\mathrm{g}-\mathrm{HCH}$ ADRIS "no harmful effects" concentration of $30 \mathrm{ug} / \mathrm{Kg}$. 
Am. J. Sci. Ind. Res., 2013, 4(1): 22-30

Table 2: Sum OCs in water, sediment and biota of Lagos Lagoon

\begin{tabular}{|c|c|c|c|c|}
\hline LOCATION & SAMPLES & $\begin{array}{l}\text { Sum OCs } \\
(\mathrm{ng} / \mathrm{g})\end{array}$ & $\begin{array}{l}\text { Sum OCs } \\
\text { (ng/g lipid) }\end{array}$ & $\begin{array}{l}\% \text { Lipid or } \\
\text { organic carbon }\end{array}$ \\
\hline \multirow[t]{3}{*}{ Five Cowrie Creek } & Water (ng/mL) & 0.00 & & \\
\hline & Sediment & 0.00 & 0.00 & 0.80 \\
\hline & F15: Catfish (Chrysichthys Nigrodigitatus) & 35.95 & 72.98 & 49.26 \\
\hline \multirow[t]{7}{*}{ Unilag lagoon front } & Water $(\mathrm{ng} / \mathrm{mL})$ & 0.02 & & \\
\hline & Sediment & 8.65 & 240.27 & 3.6 \\
\hline & SS: Crayfish (Penaeus) & 21.03 & 1569.40 & 1.34 \\
\hline & CS: Young blue crabs(Callinectus amnicola) & $69.40^{*}$ & 3183.49 & 2.18 \\
\hline & F4: Tilapia (Saratherod-on melanotheron) & 39.94 & 1512.88 & 2.64 \\
\hline & F5: Tilapia (Tilapia guineensis) & 47.40 & 2443.30 & 1.94 \\
\hline & F9: Megalops (Tarpon Atlanticus) & 32.09 & 1062.58 & 3.02 \\
\hline \multirow[t]{7}{*}{ Okobaba } & Water (ng/mL) & 0.029 & & \\
\hline & Sediment & 17.68 & 165.85 & 10.66 \\
\hline & F1: Agaza (Caranx hippos) & $63.90^{*}$ & 1800.00 & 3.55 \\
\hline & F2: Mullet (Mugil cephalus) & 18.53 & 548.23 & 3.38 \\
\hline & F11: African red snapper (Lutjanus agennes) & 29.93 & 731.79 & 4.09 \\
\hline & F12: Grunter (Pomadasys Jubelini) & 18.13 & 1154.78 & 1.57 \\
\hline & $\begin{array}{l}\text { F20: African brown snapper (Lutjanus } \\
\text { Dentatus ) }\end{array}$ & 32.93 & 1184.53 & 2.78 \\
\hline \multirow[t]{5}{*}{$\begin{array}{r}\text { Mouth of Ogun } \\
\text { River }\end{array}$} & Water (ng/mL) & 0.01 & & \\
\hline & Sediment & 22.05 & 2563.95 & 0.86 \\
\hline & $\begin{array}{l}\text { SB: Pink shrimps (Macrobranchium } \\
\text { Vollenloevensis) }\end{array}$ & 8.41 & 404.33 & 2.08 \\
\hline & CB: Matured blue crabs (Callinectus amnicola) & 29.96 & 992.05 & 3.02 \\
\hline & CE: Crab eggs & $55.22^{*}$ & 308.84 & 17.88 \\
\hline \multirow[t]{4}{*}{ Aja } & Water (ng/mL) & 0.28 & & \\
\hline & Sediment & 23.17 & 127.31 & 18.20 \\
\hline & F3: Barracuda (Sphyraena barracuda) & 3.38 & 482.71 & 0.7 \\
\hline & F10: Mackerel (Scomberomorus Tritor) & 14.82 & 1646.67 & 0.90 \\
\hline \multirow[t]{3}{*}{$\begin{array}{l}\text { East of Palava } \\
\text { Island }\end{array}$} & Water (ng/mL) & 0.01 & 250.00 & 0.96 \\
\hline & Sediment & 2.40 & 1750.00 & 1.24 \\
\hline & F6: Bonga (Edmalosa fimbriata) & 21.70 & & \\
\hline
\end{tabular}

The total concentrations of $\mathrm{HCHs}$ in fish samples reported by (Anyakora et al., 2008) for Lagos lagoon ranged from 3.27-10.55 ppm wet weight, the highest concentration being detected in Tilapia while the 
lowest concentration was detected in catfish. In our result $\mathrm{HCH}$ concentrations ranged from 0.78 to $22.72 \mathrm{ng} / \mathrm{g} \mathrm{d}$. w., the lowest being found in Barracuda (Sphyraena barracuda) while the highest was found in Tilapia (Tilapia guineensis) and $22.01 \mathrm{ng} / \mathrm{g}$ was found in catfish. These two reports from the Lagos Lagoon tallied well though there were some variations possibly due to the different sample locations used in the two assessments. Sample locations were not specified by (Anyakora et al., 2008) and so comparison of results by locations was not possible. Our multifactorial analysis of variance for water and sediments at different locations on the Lagos Lagoon revealed that mean concentrations of the OCs were statistically significantly different in the two media ( $P$ value of 0.001), the key factor responsible for this being the prevailing environmental condition or the nature (e.g. Polarity, organic nature etc.) of the media analyzed (Mackay et. al, 1997). The total OCs ranging from 2.72-20.57 $\mathrm{ng} / \mathrm{g}$ wet weight has been reported in fish from Lagos lagoon (Anyakora et al., 2008), Our result in this study reveals the sum OCs ranging from $3.38 \mathrm{ng} / \mathrm{g}$ in the fish Barracuda (Sphyraena barracuda) to $69.40 \mathrm{ng} / \mathrm{g}$ dry weight in Young blue crabs (Callinectus amnicola). The sum OCs of $55.22 \mathrm{ng} / \mathrm{g}$ in Crab eggs, 63.90ng/g in Agaza (Caranx hippos), and $69.40 \mathrm{ng} / \mathrm{g}$ in Young blue crabs (Callinectus amnicola) obtained in this study were higher than the sum OCs of the source clams of $48 \mathrm{ug} / \mathrm{Kg}$ from Potomac (Fort Foote). OC concentrations were higher than the Federal Environmental Protection Agency (FEPA) allowable limit of $<0.01 \mathrm{ppm}$. Lipid normalization of biota and organic carbon normalization of the sediment samples from different sites caused the variation in concentration by sample type and by location to disappear in many cases (table 2). Concentrations at various locations were altered in respect to the organic carbon contents at those locations as a result of the influence of organic carbon fraction on the partitioning capacity of the chemicals in the sediments of the lagoon. This is in agreement with the statement that, in addition to sorption to sediment, PBTs in aquatic environments bind to dissolved humic material, (Gobas and Arnot 2004). Sum sediment OCs was highest at Aja $(23.71 \mathrm{ng} / \mathrm{g} \mathrm{d}$. w.) while the lowest concentration was at East of Palava Island (2.40ng/g d. w.). On organic carbon normalization, the value at Aja became the least $(127.31 \mathrm{ng} / \mathrm{g}$ organic carbon while the value at the Mouth of Ogun River (22.05ng/g d. w.) became the highest (2563.95ng/g organic carbon). Relating the sediment and biota concentrations at Aja before and after normalization, the sediment concentration $(23.17 \mathrm{ng} / \mathrm{g} \mathrm{d}$. w.) which was higher than the biota concentrations (3.38 and $14.82 \mathrm{ng} / \mathrm{g}$ d. w. for barracuda and mackerel respectively) became the lowest (127.31ng/g organic carbon) compared to the values for barracuda and mackerel (482.71 and $1646.67 \mathrm{ng} / \mathrm{g}$ lipid respectively) after normalization.

Biota Sediment Accumulation Factors (BSAFs) of OCs for fish and invertebrates: Table 3 shows the different BSAFs of OCs for invertebrates. The BSAF for p,p'DDT in young blue crabs (CS) was 8.70. BSAFs for p,p'DDE ranged from 3.58 to 7.83 in matured crabs and young crabs respectively. BSAFs for $p, p$ 'DDD ranged from 2.83 to 25.15 in crab eggs and matured crabs respectively. The BSAFs were assessed only for the DDTs and they were all above 1. These results indicated that none of the invertebrates could metabolize and excrete any of these compounds. This revealed that these compounds bioaccumulated highly in the invertebrates. Table 4 shows the different BSAFs of OCs for fish. Only the BSAFs for $b-\mathrm{HCH}$ and the DDTs were assessed in eleven fish samples. BSAFs for $p, p$ 'DDE which was the most predominant OC in the samples ranged from 0.34 in mullets to 10.48 in tilapia. BSAFs for b-HCH was assessed only in samples (barracuda, bonga, and mackerel) and ranged from 1.76 in bonga to 97.81 in mackerel. BSAFs for p,p'DDE in agaza (F1), mullets (F2), African red snapper (F11), and grunter (F12) were all below 1 as shown in table 4 . This indicated that these fishes were able to metabolize p,p'DDE. No fish was able to metabolize DDD, DDT and $b-\mathrm{HCH}$ as indicated by their BSAF values of above 1 in table 4 . Fig. 1 shows that there were very poor correlations between BSAFs and Log Kow for the different biota samples as indicated by the $R^{2}$ value of 0.01 possibly due to the lack of sedentary behavior in the biota assessed.

Table 3: BSAFs of OCs for invertebrates

\begin{tabular}{|l|r|r|r|}
\hline OCs & \multicolumn{1}{|l|}{ CS } & \multicolumn{1}{|l|}{ CB } & \multicolumn{1}{l|}{ CE } \\
\hline$p, p^{\prime}$ DDE & 7.83 & 3.58 & 5.55 \\
\hline$p, p^{\prime}-$ DDD & 9.28 & 25.15 & 2.84 \\
\hline$p, p^{\prime}-$ DDT & 8.70 & & \\
\hline
\end{tabular}


Table 4: BSAFs of OCs for fish

\begin{tabular}{|l|l|l|l|l|l|l|l|l|l|l|l|}
\hline OCs & F1 & F2 & F3 & F4 & F5 & F6 & F9 & F10 & F11 & F12 & F20 \\
\hline b-HCH & & & 12.21 & & & 1.76 & & 97.81 & & & \\
\hline p,p'DDE & 0.76 & 0.34 & & 10.48 & 9.62 & & 6.96 & & 0.45 & 0.80 & 1.36 \\
\hline $\begin{array}{l}\text { p.p'- } \\
\text { DDD }\end{array}$ & & & & 21.77 & 24.85 & & 16.78 & & & & \\
\hline $\begin{array}{l}\text { p.p'- } \\
\text { DDT }\end{array}$ & & & & & 7.90 & & 4.75 & & & & \\
\hline
\end{tabular}

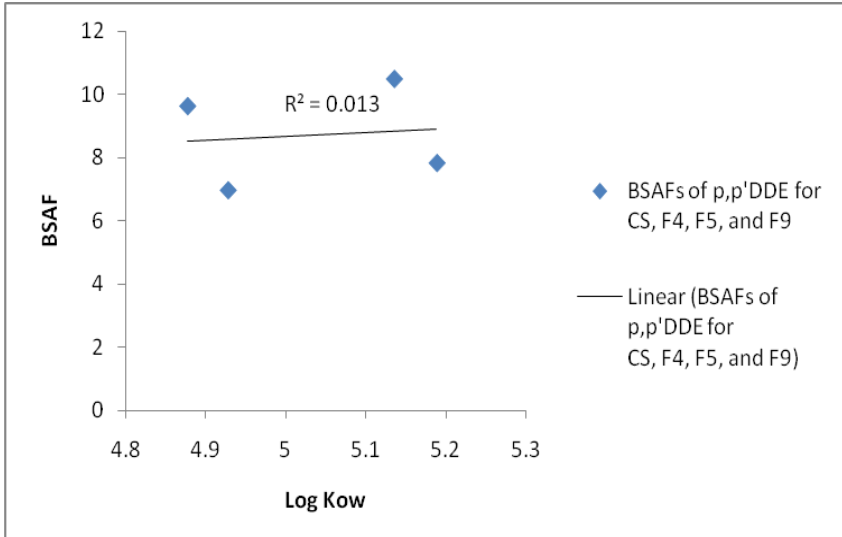

Fig. 1: BSAF versus Log Kow of p,p'DDE for CS, F4, F5, and $\mathrm{F} 9$

Percent distribution of OCs in different sample types: The distribution of OCs in Fig.2 shows that young crabs had the highest percent distribution of $32 \%$, Tilapia (F5) had $22 \%$, Tilapia (F4) had $18 \%$ and Megalops $15 \%$, while sediment had just $4 \%$. The distribution of OCs to water was $0 \%$ which reflected high hydrophobicity. High bioaccumulations of the OCs were observed. Young crabs bioaccumulated the OCs most with sum OC concentration of $69.40 \mathrm{ng} / \mathrm{g} \mathrm{d} / \mathrm{w}$. and $3183.49 \mathrm{ng} / \mathrm{g}$ lipid weight. This indicated that young crabs may be a useful biological indicator for the OCs. Mean percent distribution of OCs in fish and invertebrates revealed the OCs present in high concentrations in both the fish and invertebrates are shown in Fig. 3. This revealed the close similarities in the bioaccumulation patterns of OCs in fish and invertebrates, though the concentrations in the invertebrates were generally higher than what were obtained in the fishes. The bioaccumulation pattern showed b-HCH> p,p'DDE > $p, p^{\prime} D D D>p, p^{\prime} D D T$ in both fish and invertebrates.

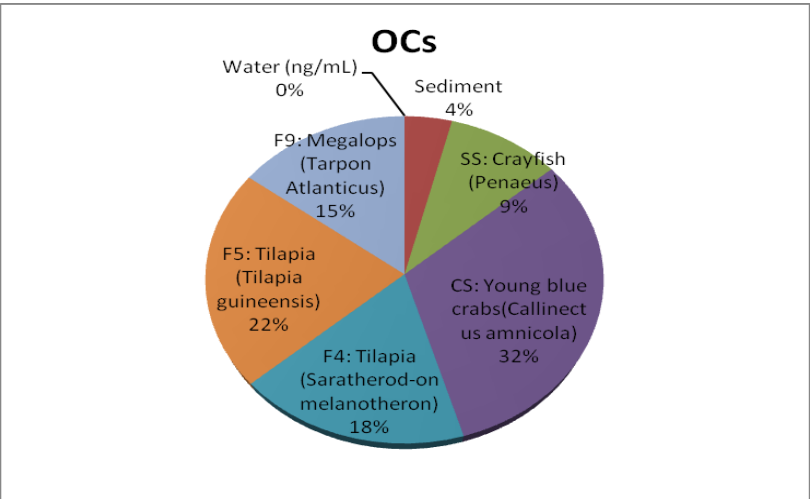

Fig. 2: Distribution of OCs in different sample types

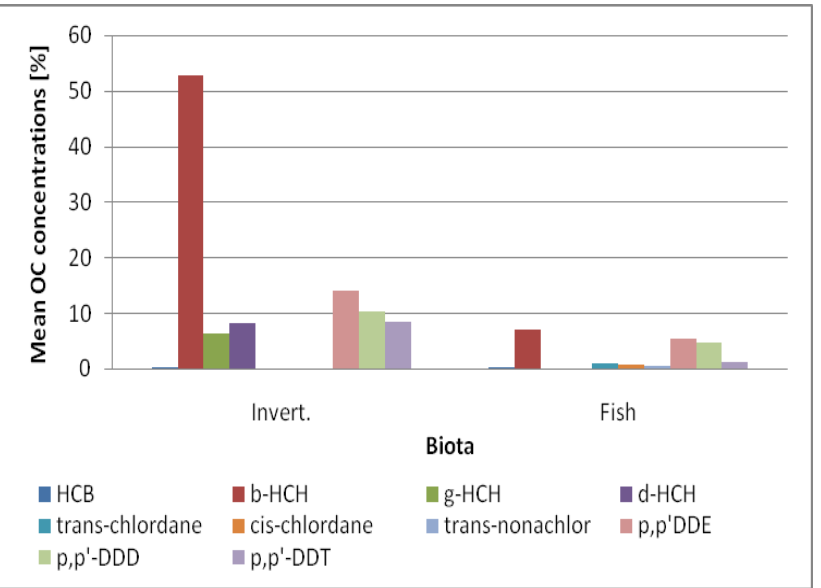

Fig.3: Mean \% OCs in fish and invertebrates

Percent distribution of OCs in invertebrates: Beta$\mathrm{HCH}(100 \%$ of total OCs) which was the dominant $\mathrm{OC}$ in all most of the invertebrates happened to be the only OC (100\% of total OCs) found in the shrimps. None of the DDTs was found in either crayfish or shrimps; they were only bioaccumulated by the crabs, though they were taken sampled same site. The invertebrates accumulated only one of the legacy pesticides (pesticides that have been characterized as pollutants since the 1960's and 
1970's are often referred to as legacy pesticides, which include pesticides such as DDTs, Chlordanes and Toxaphene). Of the invertebrates, cray fish and shrimps were completely free of the legacy pesticides, and were dominated by the $\mathrm{HCHs}$. The $\mathrm{HCH}$ represented $98.79 \%(\mathrm{~b}-\mathrm{HCH}$ and $\mathrm{d}-\mathrm{HCH}$ which were 16.00 and $4.78 \mathrm{ng} / \mathrm{g} \mathrm{d}$. w. respectively) of the total OCs in crayfish. Beta- $\mathrm{HCH}$ was found in high concentrations in all the invertebrates $(76.09,100$, 64.44 , and $22.95 \%$ of total OCs amounting to 16.004 , $8.41,19.31$ and $15.93 \mathrm{ng} / \mathrm{g} \mathrm{d}$. w. for crayfish, shrimps, matured crabs and young crabs respectively) except in the crab eggs. Beta-HCHs gave the mean percent concentration of $52.70 \%$ of the total OCs in the invertebrates. Gamma-HCH (Lindane) was obtained (30.94\% of the total OCs) only in the crab eggs (Fig. 4). This is because b-HCH is more persistent than $\mathrm{g}$ $\mathrm{HCH}$ and unacceptably high residues have been reported in food originating from countries where technical $\mathrm{HCH}$ is still being used (Environmental Health Criteria 123). Also g-HCH appears to be rapidly eliminated by vertebrates and residues in free-living vertebrates and invertebrates were found to be low when the compound was widely used in agriculture (Walker 2009).

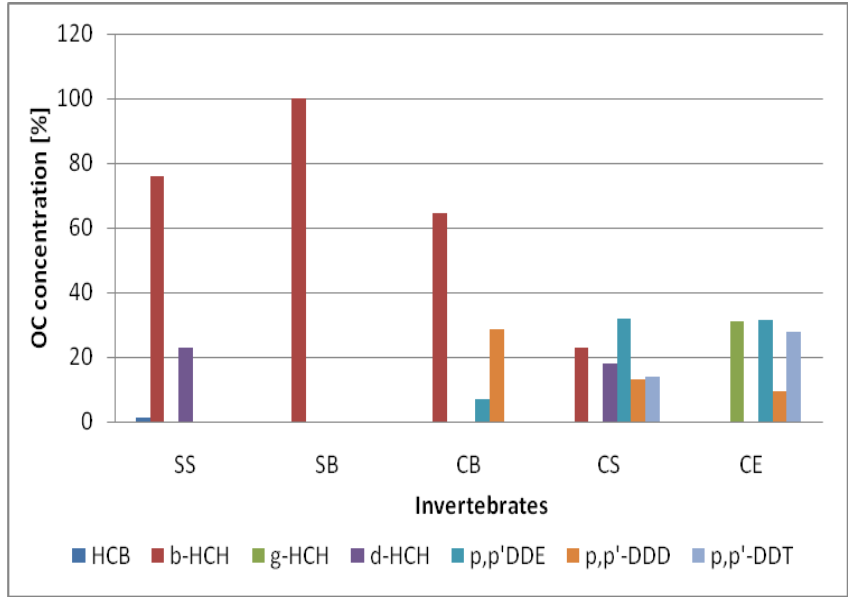

Fig. 4: Percent distribution of OCs in invertebrates from Lago

For classification of the target contaminants' carcinogenicity, $\mathrm{HCH}$ and its isomers and DDT and its metabolites belong to the category of "possibly carcinogenic to humans", since 2,3,7,8-TCDD (from the dioxins group) is classified as "carcinogenic to humans" (IARC, 2006). For every carcinogenic substance, there is a risk of developing cancer at any dose different from zero. Calculated excess cancer risk based on estimated exposure doses of 16.414 $\mu \mathrm{g} / \mathrm{kg}$-day for adults and $0.122 \mu \mathrm{g} / \mathrm{kg}$-day for children in $\mu \mathrm{g} / \mathrm{kg}$-day revealed $1.50 \%$ excess cancer for $\mathrm{b}$ $\mathrm{HCH}$ (Carmen et al., 2002). From our study, $19.31 \mathrm{ng} / \mathrm{g} \mathrm{d}$. w. of b-HCH was found in the matured crab tissue. If one gramme of this crab is consumed by an adult, over $1.50 \%$ of the population eating these crabs could develop cancer due to exposure to these contaminants. Similarly, (Carmen et al., 2002) calculated excess cancer risks of $0.450,0.045$, and $0.209 \%$ for adults consuming up to $10.907,1.625$, and $5.143 \mu \mathrm{g} / \mathrm{kg}$-day of DDE, DDD, and DDT respectively. Comparing the DDE, DDD, and DDT concentrations obtained in invertebrates in this study (Fig. 5), the excess cancer risks for these contaminants are two to three times more than what was obtained by (Carmen et al., 2002). The young crabs were the most affected because they accumulated b- $\mathrm{HCH}$ as well as the DDTs in appreciable concentrations.

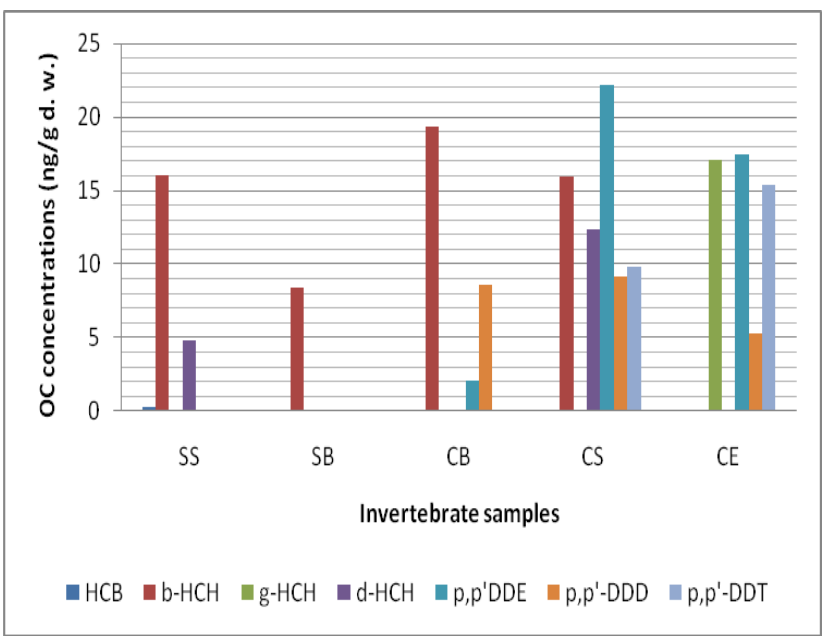

Fig. 5: OC concentrations in invertebrates from Lagos lagoon

Percent distribution of OCs in fish: In Lagos lagoon, b-HCH was also found in all fish samples ranging from 3.16 to $22.72 \mathrm{ng} / \mathrm{g} \mathrm{d}$. w., giving the mean $\%$ concentration of 37.42 of the total OCs in fish samples. $\mathrm{G}-\mathrm{HCH}$ was completely absent in all the fish samples (Fig. 3) because it is more polar and more water soluble than most other OCs and is metabolized relatively rapidly to water-soluble products such as chlorophenols. The DDTs in fish ranged from 1.29 to $13.33 \mathrm{ng} / \mathrm{g} \mathrm{d}$. w. (Fig. 7), with DDE, DDD, and DDT being 28.42, 24.60, and 3.93\% respectively. $P$, p'DDT has very low solubility in water and is highly lipophylic ( $\log \mathrm{Kow}=6.36$, thus there is a high potential for bioconcentration and 
Am. J. Sci. Ind. Res., 2013, 4(1): 22-30

bioaccumulation (Walker 2009). The most widespread residue of DDT found in the environment have been p,p'DDE, p,p'DDT, and p,p'DDD. Very long half-lives have been reported for $p, p$ 'DDE in terrestrial animals, approaching 1 year in some species, and greatly exceeding the comparative values for the other compounds (Cooke ad Stringer 1982). From the results in Figs. 3 to 7, p,p'DDE was the most bioaccumulated of the DDT group by all the fish and invertebrates. This agreed with the report that p.p'DDE was found to be more stable and persistent (refractory) than either p,p'DDT or $p, p$ 'DDD and underwent strong biomagnifications with transfer along food chain (Walker 2009). Though p,p'DDE was found to bioaccumulate more than other DDT groups, Fig. 3, the report by (Walker 2009) that $p, p$ 'DDE is less toxic than p,p'DDT, where dehydrochlorination of $p, p^{\prime} D D T$ represents a detoxication mechanism, rules out high risk at this level of bioaccumulation. DDT has caused population declines of predatory predatory birds in North America due to egg-shell thinning, brought about by its highly persistent metabolite p,p'DDE (Walker 2009). For mammals $L_{50}$ (acute oral) value for p,p'DDT ranging between 100 and $2500 \mathrm{mg} / \mathrm{Kg}$ have been reported by (Edson et al., 1966). In addition to the $\mathrm{HCHs}$ and the DDTs, the legacy pesticide, the chlordanes were found in only one sample (agaza) out of the 12 fish samples studied. $\Sigma$ Chlordane (cischlordane, trans-chlordane and trans-nonachlor), concentrations in agaza (33.99 $\mathrm{ng} / \mathrm{g} \mathrm{d}$. w. exceeded the screening value of $30 \mathrm{ng} \mathrm{g}-1$. This value accounted for $53.20 \%$ of the total OCs in this fish, agaza which happened to remain the most contaminated even by the OCs.

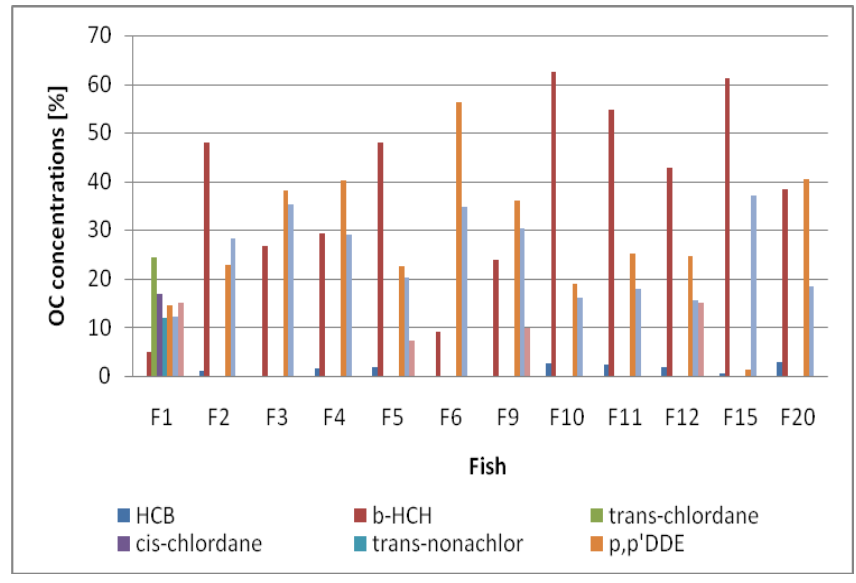

Fig. 6: Percent distribution of OCs in fish from Lagos lagoon

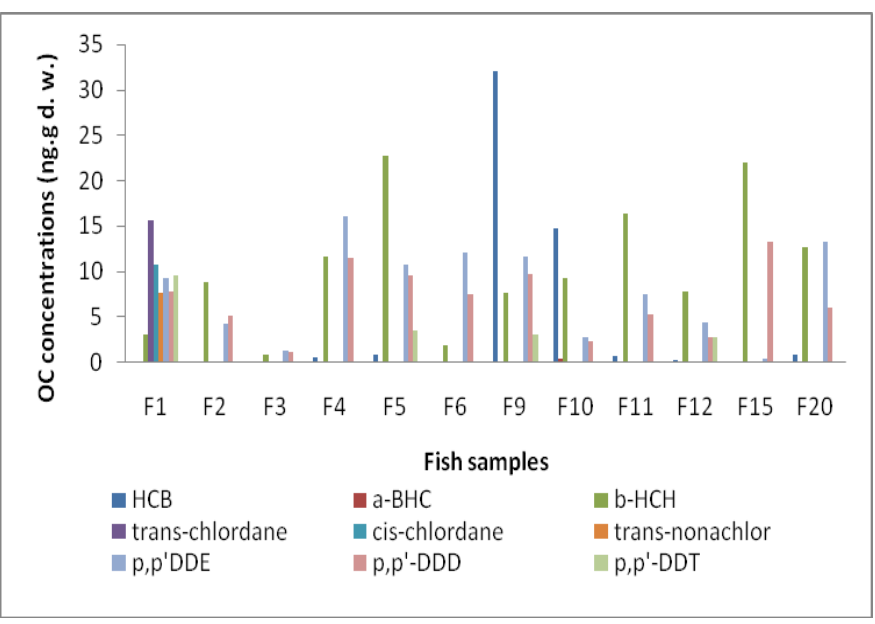

Fig. 7: OC concentrations in fish from Lagos lagoon

\section{CONCLUSION:}

The aim of this study was to provide baseline information on the level of OCs, their bioaccumulation and the risk they pose to humans that depend on fish and invertebrates from the Lagos lagoon for food. Beta-HCH and p,p'DDE were identified as the dominant $O C$ in the Lagos lagoon. Legacy OCs were found in the biota and the excess cancer risks to humans were estimated and found to be above zero in many cases, which indicated a high risk of developing cancer. $\mathrm{HCH}$ and its isomers and DDT and its metabolites which belong to the contaminant category that are "possibly carcinogenic to humans" were bioaccumulated to appreciably high concentrations. It was discovered that among the invertebrates in the Lagos lagoon, young and matured crabs posed the highest risk of cancer to humans. Among the fishes, $\Sigma$ Chlordane (cischlordane, trans-chlordane and trans-nonachlor), concentrations in agaza exceeded the screening value, thus indicating a high risk in the consumption of this fish by humans. Consumption of Crab eggs, Matured crabs, Young blue crabs (Callinectus amnicola) and Agaza (Caranx hippos), and some other seafoods from the Lagos lagoon could pose a high risk of $\mathrm{OC}$ health effects on humans as these biota bioaccumulated the contaminants above allowable limits.

\section{ACKNOWLEDGEMENTS}

The authors acknowledge the Great Lakes Institute for Environmental Research (GLIER), University of Windsor, Ontario, Canada for provision of facilities for analysis and the University of Lagos, Nigeria for the study leave to Mrs. Rose Alani to visit Canada. 


\section{REFERENCES}

Anyakora, C., Adeyemi, D., Ukpo, G., Unyimadu, J. P (2008). Organochlorine Pesticide Residues in Fish Samples from Lagos Lagoon, Nigeria. American Journal ofEnvironmental Sciences 4 (6): 649-653, ISSN 1553-345X (C) 2008 Science Publications

Arnot, J. \& Gobas, F. A. P. C. (2003) A gereric QSAR for assessing the bioaccumulation potential of organic chemicals in aquatic food webs. QSAR Comb Sci, 22 337-345.

Carmen Ildes R. Fróes Asmus, Herling Gregorio Aguilar Alonzo, Marisa Palácios, Alexandre Pessoa da Silva, Maria Isabel de Freitas Filhote, Daniela Buosi, Volney de Magalhães Câmara (2002). Assessment of human health risk from organochlorine pesticide residues in Cidade dos Meninos, Duque de Caxias, Rio de Janeiro, Brazil.

Colin, M. E., Bonmatin, J. M. \& Moineau, I. (2004) A method to quantify and analyze the foraging activity of honey bees: Relevance to the sublethal effects induced by systemic insecticides. Archives of Environmental Contamination and Toxicology, 47: 387395.

Cooke, B. \& Stringer, A. (1982) Distribution and breakdown of DDT in Orchad soil. Pesticide Science, 13: 545-551.

Edson, E.F., Sanderson, D.M., and Noakes, D. N., (1966). Acute toxicity data for pesticides. World review of Pest Control 5 (3) Autumn, 143-151.

EHC ((Environmental Health Criteria 202) 1998) Nonheterocyclic polycyclic aromatic hydrocarbons, Geneva, WHO.

Eljarrat, E. \& Barcelo, D. (2003) Priority lists for persistent organic pollutants and emerging contaminants based on their relative toxic potency in environmental samples. Trac-Trends Anal Chem. 22: 655-665.

Gobas, Frank A.P.C. and Arnot J A. (2004) A food web bioaccumulation model for organic chemicals in Aquatic ecosystems. Environmental Toxicology and
Chemistry, Vol. 23, No. 10, pp. 2343-2355, @ 2004 SETAC

IARC (International Agency Research Cancer). (2006). Monographs on the evaluation of carcinogenic risks to humans. $\quad$ http://monographs.iarc.fr/ENG/Classifi cation/index.php.

Lazar R, Edwards RC, Metcalfe CD, Metcalfe T, Gobas FAPC, Haffner GD. A simple, novel method for the quantitative Analysis of coplanar (non-ortho substituted) polychlorinated biphenyls in environmental samples. Chemosphere, 1992, 25: 493.

Mackay D., Shiu, W. Y., Ma, K. C. (1997) Illustrated handbook of physical chemical properties and environmental for organic chemicals, Volumes I-V. Boca Raton FL: CRC/Lewis.

MPMMG (Marine Pollution Monitoring Management Group). (1998). National Monitoring Programme Survey of the Quality of UK Coastal waters. Marine Pollution Monitoring Management Group, Aberdeen, ISBN 0953283836

Saxena, M.C., M.K.J. Siddique, A.K. Bhargava, C.R. Krishina Murti and D. Kutty, (1981). Placenta transfer of pesticides in humans. Arch Toxicol., 48: 127-134.

Walker, C. H. (2009) Organic Pollutants. An Ecotoxicological Perspective., New York., CRC press.

Webb, J.E., Hill, M.B. (1958): The Ecology of Lagos lagoon. The Topography and Physical Features of Lagos Harbour and Lagos Lagoon.

Wells, D. E. (1993) Current Developments in the Analysis of Polychlorinated Biphenyls (PCBs) including Planar and Other Toxic metabolites in Environmental Matrices. In: Barcelo D., editor. Environmental Analysis techniques applications and Qulaity Assurance. Elsevier Sci.Publ., 113-148. 1993.

Leeuwen, V. \& Vermeire (2007) Risk assessment of chemicals. An Introduction, The Netherlands, Springer.

Timbrell, J. (1999) Priciples od Biochemical Toxicology., London, Taylor and Francis. 